\title{
REFUGIADOS SÍRIOS EM CAMPINAS/SP E UM ALADDIN SEM A LÂMPADA MÁGICA
}

\author{
Victor Begeres Bisneto ${ }^{1}$
}

\begin{abstract}
Resumo: 0 drama dos refugiados sírios que buscam a Europa como solução para sobreviver à guerra em seu país que completa cinco anos, também se revela no Brasil. Baseando-se principalmente de relatos orais obtidos entre setembro e novembro de 2015, o presente artigo busca evidenciar as condições em que vivem os refugiados sírios na cidade de Campinas/ SP (segunda no Estado em número de refugiados), a forma como o poder público municipal oferece suporte a essas pessoas e qual a visão desses imigrantes sobre o conflito na Síria, de modo a oferecer um ponto de vista mais original e sem a intermediação dos grandes veículos de comunicação.
\end{abstract}

Palavras-chaves: refugiados sírios, Campinas/SP, migração, crise humanitária, conflito na Síria.
Abstract: The sad plight of Syrian refugees seeking Europe as a solution to survive the war in their country which now completes five years, is also revealed in Brazil. Based on oral reports obtained between September and November 2015, this article seeks to highlight the conditions in which the Syrian refugees live in the city of Campinas/SP (the second in the state in number of refugees), the way the municipal government supports these people and what is the vision of these immigrants of the conflict in Syria, in order to offer a more unique perspective without the intermediation of the major media.

Palavras-chaves: syrian refugees, Campinas/SP, migration, humanitarian crisis, Syria conflict.

\section{Introdução}

Nos últimos meses temos acompanhado de forma cada vez mais flagrante a dramática fuga de sírios em razão do conflito em seu país que se encaminha para o quinto ano de violência e indefinição. Já são cerca de 400 mil mortos ${ }^{3}$ e quase 5 milhões de refugiados ${ }^{4}$. Barcos lotados e botes infláveis vulneráveis às intempéries do Mediterrâneo repletos de emigrantes, grande parte sírios, se tornaram imagens banais. Indo na contramão da história do bloco europeu, novos muros e cercas passaram a ser construídos em razão dessas ondas imigratórias que só no ano de 2015 quase 300 mil pedidos de asilo foram

\footnotetext{
${ }^{1}$ Geógrafo formado pela Unicamp, mestre em geografia humana (USP) e doutorando em história social (USP). Também é professor de geografia no Liceu Salesiano Nossa Senhora Auxiliadora de Campinas. Já atuou como assessor técnico da secretaria de planejamento urbano de Campinas/SP. E-mail: victor.bisneto@ yahoo.com.br ou victor.bisneto@usp.br

${ }^{2}$ Geógrafo formado pela Unicamp, mestre em geografia humana (USP) e doutorando em história social (USP). Também é professor de geografia no Liceu Salesiano Nossa Senhora Auxiliadora de Campinas. Já atuou como assessor técnico da secretaria de planejamento urbano de Campinas/SP. E-mail: victor.bisneto@ yahoo.com.br ou victor.bisneto@usp.br

${ }^{3} \mathrm{http}: / / w w w . a l j a z e e r a . c o m / n e w s / 2016 / 04 /$ staffan-de-mistura-400000-killed-syria-civil-war-160423055735629. html (acesso em 28/06/2016).

${ }^{4} \mathrm{http}$ ://www.acnur.org/que-hace/respuesta-a-emergencias/emergencia-en-siria/ (acesso em 28/06/2016)
} 
aceitos pela União Europeia dentre os cerca de 1 milhão de pedidos ${ }^{5}$.

Contudo, outra rota não tão noticiada é a dos imigrantes sírios que atravessam o Atlântico em direção ao Brasil, país que tem concedido refúgio a mais sírios do que alguns dos mais importantes portos de destinos de refugiados na Europa ${ }^{6}$.

Para o CONARE7 (Comitê Nacional para os Refugiados), órgão interministerial que cuida dos assuntos referentes aos refugiados, o Brasil possui atualmente 8.863 refugiados, de 79 nacionalidades distintas. Dentre eles, os sírios somam 2.298 indivíduos. Em razão do aumento do fluxo de refugiados, o CONARE publicou a resolução normativa no17, facilitando a entrada no Brasil de quem queira solicitar refúgio em decorrência do conflito sírio, por meio da emissão de um visto de turista válido por 90 dias.

O Estado de São Paulo é aquele que mais recebe pedidos de vistos para refugiados, cerca de $40 \%$ do total. Com relação ao número de sírios no Estado, em junho de 2015 os dados apontavam para cerca de $3.809^{8}$. A capital paulista é por sua vez a cidade com mais solicitantes: 3.276. Logo atrás está a cidade de Campinas, recorte territorial escolhido como base para esse artigo pelo peso que a cidade possui no tocante à presença de refugiados sírios e por ser o local onde vivem as pessoas entrevistadas. Os dados obtidos junto à Câmara Municipal e à Comissão Especial de Estudos (CEE) que acompanha o influxo de refugiados na cidade, contabilizam 37 famílias ou cerca de 218 pessoas 9 .

Os números exibidos servem apenas para quantificar friamente uma realidade que tem histórias de vida, rostos, sofrimentos e crenças. 0 bombardeio de informações mais nos confunde do que nos esclarece, impondo filtros quantitativos e interpretativos à realidade. É dessa maneira que banalizamos e naturalizamos os acontecimentos por mais trágicos que possam ser. Para Kosik (1976:15) vivemos em um mundo dominado pela "pseudo-concreticidade", aquele "dos fenômenos que povoam o ambiente cotidiano e a atmosfera comum da vida humana, que, com a sua regularidade, imediatismo e evidência, penetram na consciência dos indivíduos agentes, assumindo um aspecto independente e natural". Thompson (2000:14) também assevera que "a informação que obtemos só a partir das estatísticas não pode explicar porque pessoas de algumas culturas migram frequentemente e outras não. Para isso, os testemunhos narrativos são essenciais".

No intuito de rompermos essa "pseudo-concreticidade", mergulhando na essência dos fatos sem se ocupar apenas com as aparências e seus intermediários que podem nos desviar da compreensão de uma realidade mais tangível, estabeleci contato com 11 refugiados sírios em Campinas/SP e sua região metropolitana com o objetivo de dar voz ${ }^{5} \mathrm{http}: / /$ www.bbc.com/news/world-europe-34131911 (acesso em 28/06/2016).

${ }^{6} \mathrm{http}: / /$ www.bbc.com/portuguese/noticias/2015/09/150904_brasil_refugiados_sirios_comparacao_ internacional_lgb (acesso em 28/06/2016).

${ }^{7} \mathrm{http}: / /$ www.acnur.org/t3/portugues/recursos/estatisticas/dados-sobre-refugio-no-brasil/ (acesso em 28/06/2016)

${ }^{8} \mathrm{http} / /$ www.redebrasilatual.com.br/cidadania/2015/06/brasil-da-exemplo-de-acolhimento-derefugiados-aos-paises-ricos-diz-representante-da-onu-1318.html (acesso em 28/06/2015). 0 número de pedidos de refúgio no estado aumentou mais de $1.000 \%$ entre 2010 e 2014, saltando de 310 para 3.612.

${ }^{9}$ A Sociedade Islâmica de Campinas estima em 39 famílias o número de refugiados sírios. 
a esses indivíduos a partir de entrevistas e encontros para trazer à luz grupos de pessoas escondidas da história (Perks, 1998), dar uma identidade àqueles que a mídia e muitas organizações enxergam como uma estatística.

0 presente artigo também se preocupará em destacar informações que nos permitam entender e avaliar a complexidade da guerra civil na Síria do ponto de vista desses refugiados e como têm vivido em um local tão diferente e distante como o Brasil. Por que a escolha de um país tão longínquo? Quais as formas de amparo encontram aqui? Qual a percepção dessas pessoas com relação ao conflito em seu país? Enfim, pretende-se identificar os efeitos colaterais do conflito sírio sob o viés de suas vítimas que deixaram para trás o som ameaçador de bombas e da escassez de bens e serviços de toda ordem, para se deparar com outro desafio mais silencioso, mas não menos difícil, o de iniciar sua vida do zero em um país que acolhe, mas sem promessas oficiais de suporte. Vivendo como um Aladdin ${ }^{10}$ sem sua lâmpada mágica.

As conversas que tive com meus informantes sírios não seguiram um roteiro de perguntas pré-determinadas que necessariamente precisassem serabordadas. Afinal, como explica Portelli (1998:71), "entrevistas com estruturas rígidas podem excluir elementos cuja existência ou relevância eram previamente desconhecidas do entrevistador. Tais entrevistas tendem a confirmar o quadro de referência prévio do historiador". Claro que os prévios conhecimentos sobre o conflito na Síria e sobre o Oriente Médio de um modo geral exerceram maior interesse sobre certos eventos e situações. Contudo, especialmente nos primeiros contatos, preferi seguir o ensinamento de Portelli (ibidem) em que "é preciso que o pesquisador 'aceite' o informante, dar prioridade ao que ele ou ela desejam falar, do que aquilo que o pesquisador quer ouvir, deixando as questões não respondidas para depois ou outra entrevista".

Outro ponto importante para o leitor acompanhar o desenrolar dos fatos expostos pelos refugiados em Campinas/SP é que em vários momentos tentei reproduzir exatamente o que ouvi e vi, como falas e suas entonações acompanhadas por gestos que ajudam a priorizar certos assuntos em detrimento de outros. No entanto, há que se tomar cuidado em não apenas focar em como eles dizem o que dizem, mas principalmente sobre que tipo de reflexão temos que ter com base naquilo que os entrevistados realmente descrevem (Thompson, 2000).

Para fins de organização dos fatos, dividi os entrevistados em dois núcleos. Um deles centralizado em Issa e o outro em Alaa El-Deen e sua família.

Com Issa, tive três encontros. 0 primeiro foi em um restaurante de uma também recém imigrada família Síria; o segundo na casa do irmão de Issa quando fui entregar

\footnotetext{
${ }^{10}$ Alaa El-Deen é um dos entrevistados e ao se apresentar, citou em tom jocoso o personagem do desenho para
} pronunciar seu nome. Isso será explorado posteriormente. Aproveito para prevenir o leitor que me reservo o direito, em respeito àqueles com quem tive contato, em oferecer apenas seus primeiros nomes e de não publicar fotos, uma vez que em cada encontro me era pedido para que não houvesse fotografias por questões de segurança visto que ainda há membros de suas famílias vivendo na Síria e porque temem quaisquer represálias em razão de sua fuga. Os encontros aconteceram entre setembro e novembro de 2015 na cidade de Campinas/SP. 
algumas doações; e o terceiro no restaurante em que passou a trabalhar, localizado em um shopping da cidade ${ }^{11}$.

Quanto ao segundo núcleo, tive apenas um encontro que se deu na Sociedade Islâmica de Campinas uma vez que essa família quatro dias após nossa conversa deixou o Brasil por motivos que serão esclarecidos posteriormente.

\section{Issa}

No dia 25 de setembro de 2015, eu e um amigo egípcio chamado Hossan fomos a um modesto restaurante no centro da cidade, aberto há pouco mais de seis meses, dirigido por uma família de refugiados da Síria que chegou à cidade há dois anos aproximadamente. A família é composta por quatro pessoas: o pai Abu Kamel, sua esposa e duas filhas, antes moradores da cidade de Aleppo, norte da Síria. Abu Kamel é engenheiro. Uma de suas filhas, médica, estava ao caixa quando lá estive. Hossan me ajudou com a tradução e na fluidez da conversa, pois entre os presentes, todos ainda tinham dificuldades com o idioma local.

Logo de início, ao ser apresentado, perguntaram-me se eu era jornalista - talvez por eu estar portando uma bolsa que lembra aquelas de carregar câmeras fotográficas. Mas logo os saudei e respondi em meu árabe básico: "Assalamu aleikum! Aná ustádon" (Que a paz de Deus esteja com vocês! Eu sou professor). Todos se surpreenderam e sorriram quebrando um pouco o gelo. Avisei que sabia um pouco da língua, mas que não conseguiria manter toda a conversa em árabe.

Enquanto almoçávamos, cerca de quatro sírios, todos recém-chegados ao Brasil, estavam à mesa ao lado conversando, entre eles Issa, que se tornaria um dos meus principais contatos, seu irmão Fadi, e seus dois primos Jouny e Elias. Aos poucos fui me inserindo à conversa mediada por Hossan que já conhecia o dono do restaurante Abu Kamel, que por sua vez nos apresentou aos demais e se juntou a nós para falar sobre sua vinda ao Brasil. Muito se falou sobre isso e pouco sobre a situação do país de onde vieram, apesar de minha insistência em algumas perguntas e curiosidades sobre o conflito. Sobre isso, todas elas eram respondidas de forma superficial e genérica. Imagino que ainda fruto do trauma vivido, dos entes perdidos e talvez por certa desconfiança com relação à minha pessoa, ainda estranha para todos.

Todos demonstraram gratidão e alegria com a recepção e hospitalidade dos brasileiros. Abu Kamel afirma que "para brasileiros, sírios não são estrangeiros, eles nos abraçam". Issa complementa dizendo que "quando sabem que venho de Síria, ficam com pena, me chamam de 'tadinho' mas me ajudam". Todos foram unânimes em dizer que escolheram o Brasil por causa da facilidade em se obterem vistos, algo proporcionado entre outras coisas, pela resolução n.17 do CONARE, citada anteriormente.

Quando perguntei a Abu Kamel quais os motivos que os levaram a sair de seu

\footnotetext{
${ }^{11}$ Contudo, os relatos se basearão no primeiro e no terceiro encontro.
} 
país, se eram devido ao governo de Bashar Al-Assad ou à presença de grupos extremistas como o Estado Islâmico (EI), Abu Kamel então pegou um porta-guardanapo que estava sobre a mesa e disse em um português frágil e carregado de sotaque: "esse minha casa. Aqui, governo. Aqui, Daesh ${ }^{12}$. Eu sair por causa da guerra”. Deixou claro que sua casa ficava exatamente na linha de fogo entre o governo e os jihadistas. Ainda afirmou que perdeu alguns amigos e vizinhos e que já não reconhecia o bairro em que vivia. A falta de água, energia elétrica, medicamentos e alimentos completam o quadro que determinou a vinda de sua família para o Brasil. Nota-se que a resposta foi um tanto evasiva não deixando claro quem é o inimigo e o causador de todo o sofrimento bem como se é ou não simpatizante do governo de Bashar Al-Assad.

Abu Kamel logo pediu licença e se retirou para cuidar dos afazeres do restaurante. A partir desse momento a conversa se concentrou entre mim, Hossan e Issa, que era quem estava há mais tempo no Brasil e falava um português mais inteligível. A conversa se deu quase toda em árabe em respeito aos demais. Os outros apenas acenavam com a cabeça concordando com o que era dito à medida que havia a mediação de Hossan e acrescentando detalhes à memória.

Issa tem cerca de 30 anos de idade e tinha uma fábrica de roupas na Síria. Ele é casado com e tem um filho de 11 meses nascido em Campinas com a ajuda de uma equipe de médicos de um hospital local que fez o parto sem custos. Sua família tem origem basicamente de três lugares: Hama, Damasco e Homs. Seus pais também deixaram a Síria e hoje são refugiados na Jordânia. Boa parte da família, todavia, entre eles seus tios e um irmão, continuam vivendo na Síria, pois não querem deixar alguns dos negócios que ainda resistem ao conflito. Ao falar de sua família, sua voz diminui de intensidade e sua fala faz uma pausa como que de repente as memórias dessas pessoas e suas vidas viessem à tona com muita intensidade e então pondera de forma não muito lógica: "mas aqui tenho trabalho graças a Deus". Talvez pensando em voz alta como estaria sua vida caso ainda estivesse em sua terra natal. Ele complementa dizendo que

\begin{abstract}
antes da guerra, eu trabalhava, tinha algum dinheiro. Mas quando aconteceu a guerra perdi tudo. Vendi tudo o que tinha, especialmente joias de casamento para vir para cá. Fogão, geladeira e a própria casa não foram vendidos pois quase ninguém queria comprar pois também estavam em fuga. Apesar disso, achava que teria algum apoio, algo que não aconteceu. Então o peso de ter que cuidar da família é muito grande em um lugar sem ajuda.
\end{abstract}

Issa, que nesse primeiro encontro ainda estava desempregado, reclamou sobre o fato de morar todos juntos (seu irmão, dois primos, sobrinha, filho e esposa, portanto, cinco adultos e duas crianças) no mesmo quarto.

\footnotetext{
${ }^{12}$ Daesh - Forma como se referem ao grupo em árabe: Dawla Al-Islamyyia Al Iraq wa Al Sham - Estado Islâmico do Iraque e da Síria.
} 


\section{relato de campo}

O local em que estava morando ficava no centro de Campinas. Em razão do elevado valor do aluguel, cerca de mil reais por mês, disse que estava em busca de outro local. Atualmente ele mora com sua mulher e filho no bairro Matão em Sumaré, local conhecido por ser afastado do centro e com elevados índices de violência e pouca infraestrutura. 0 aluguel agora é de 800 reais segundo Issa. 0 problema que todos alegaram de forma categórica é que ao chegarem ao Brasil não sabiam que o país estava passando por uma grave crise econômica, com preços elevados encarecendo seus custos de vida.

Questionei sobre como foi chegar a um país com costumes tão diferentes da Síria, especialmente em termos religiosos e quis saber se sofreram algum tipo de preconceito no tempo em que aqui estão. Como resposta, Issa disse que não tiveram problemas quanto ao preconceito e que em termos culturais não houve grandes surpresas, afinal, ele alega que a síria também é um país plural e diverso.

Um ponto bastante sensível na conversa, até certo ponto emocionante, foi quando Issa disse, através da tradução de Hossan que "se demorar mais um pouco [para as coisas melhorarem] eu vou tentar outro caminho, vou pegar um barco e tentar a Europa. Prefiro morrer no mar a ver minha família morrer aqui aos poucos". Citou a Alemanha como exemplo e disse "que quando se chega lá, um casal ganha do governo mil euros, com seguro, com tudo, até com escola. Aqui não há nenhuma ajuda do governo, apenas de pessoas". 0 pouco de dinheiro que consegue, a maior parte vai para o aluguel. Seu filho Diego hoje frequenta uma creche, mas em caráter gratuito, algo que reforça que a solidariedade chega mais através das pessoas do que dos órgãos públicos.

Insisti novamente em descobrir maiores detalhes sobre o conflito, mas sem sucesso. As respostas continuavam vagas e genéricas. Percebi certo desconforto e então mudei de assunto, perguntando como eu poderia ser útil no sentido de contribuir com alguma ajuda face às necessidades prementes da família. Hossan então traduziu:

depende da ajuda e de quem ajuda. Se alguém doa de maneira que nós sentimos ser um tipo de obrigação ou por querer alguma vantagem em troca, não aceitamos. Aceitamos quando notamos algum carinho, quando percebem que a pessoa de fato quer ajudar, sem arrogância, sem demonstrar pena só por serem sírios.

O constrangimento quanto a receber doações é compreensível, pois na Síria eles não precisavam da ajuda, tinham emprego e recursos, algo que não condiz com a realidade atual. A questão de doações-provavelmente soa para essas pessoas com o propósito de esmola, ligada à mendicância. Aliás, é importante relembrar que Issa diz ter sido surpreendido com o número de mendigos nas ruas da cidade. Talvez para ele a esmola seja uma espécie de perversão de sua honra, pois além de paliativa, ela reforça a mendicância, tal como caracteriza Dostoievski (2013:332) ao afirmar que

o propósito, o prazer decorrente da esmola é um prazer arrogante e 


\section{relato de campo}

amoral, é o prazer do rico com a sua riqueza, com o seu poder e com a comparação da sua importância à importância do miserável. A esmola perverte tanto quem dá quanto quem recebe, e ainda por cima não atinge o objetivo porque reforça a mendicância.

Por isso, Issa tenta mostrar a todo instante que não está no país para ficar de braços cruzados e faz questão de expor sua força de vontade em trabalhar e sustentar sua família.

Ao final do almoço, alguns dos presentes tiveram que sair, inclusive Issa que tinha uma entrevista de emprego para realizar. Abu Kamel então apareceu e apresentou sua mulher que estava na cozinha preparando os pratos. Despedimos-nos de todos, com abraços e poucas palavras, pois já não havia muito que ser dito como consolo em razão da situação de todos. Abu Kamel ainda nos trouxe um livro de português para estrangeiros e disse estar aprendendo com uma voluntária e que da próxima vez que eu voltasse ele estaria melhor no idioma.

Pouco tempo depois desse encontro no restaurante de Abu Kamel, no dia 01 de novembro de 2015 me reuni novamente, agora sozinho, com Issa. Esse encontro aconteceu em um grande shopping da cidade bem em frente ao restaurante onde ele recentemente fora contratado como ajudante de cozinha.

Seu trabalho, em suas palavras, é "mais ou menos...muito difícil ônibus para Matão [onde mora]. Eu falou [falei para meu] chefe: tempo do trabalho não muito bem [bom]...eu falou precisa fazer trabalho 8 horas até 4 ou 5 horas da tarde". Nos dias em que horários de trabalho vão até mais tarde, Issa não encontra ônibus para sua casa em Matão. Assim, ele vai até o centro de Campinas e dorme na casa do seu irmão. Sobre sua família no Brasil, ele diz que seu "irmão trabalhando como pedreiro e pintor. Irmão, primos, todos trabalham com pintura, colocam telhados, pisos".

Preocupado com a questão da exploração no trabalho ${ }^{13}$, tentei conhecer um pouco mais sobre seu contrato de trabalho. Com relação ao valor que ganha no restaurante ele diz:

eu trabalho 1 h e ganho $\mathrm{R} \$ 4,90$ [R $\$ 4,90$ por hora de trabalho]. Trabalho 7 hora, 8 hora em um dia...um semana eu preciso trabalho [trabalhar] 35 hora. 35 hora, mais ou menos...R $\$ 75$. Quatro semana...até $\mathrm{R} \$ 800,00$ por mês. Mas eu tenho 'tip' [gorjeta]. 0 tip ajuda pouco...uma semana $\mathrm{R} \$ 100,00$ reais, outra $\mathrm{R} \$ 125,00^{14}$.

Finalmente consegui abordar alguns aspectos sobre o conflito na Síria e sobre as ações internacionais especificamente com a recente entrada da Rússia nos enfrentamentos.

\footnotetext{
${ }^{13}$ http://www.bbc.com/portuguese/noticias/2015/09/150929_sirios_exploracao_trabalho_fo_cc (acesso em 07/12/2015).

${ }^{14}$ Ainda que possam impactar de alguma maneira, haja vista o elevado custo de vida em uma cidade como Campinas, os valores que Issa recebe estão dentro dos parâmetros das convenções estabelecidas pelo SINDISOL (Sindicado dos Hotéis, Bares, Restaurantes e Similares) - ver: http://www.sindsol.com.br/ noticias/item/367-resumo-das-altera\%C3\%A7\%C3\%B5es-da-conven\%C3\%A7\%C3\%A3o-2015 (acesso em $07 / 12 / 2015)$.
} 
Ainda que não sejam explicações tão complexas e aprofundadas como desejado, foi uma primeira abordagem menos vaga sobre o assunto. Issa teceu alguns comentários sobre isso e chegou a defender o presidente sírio Bashar Al-Assad:

eu acho Rússia fazer bem. Porque América [EUA]...ela fazer guerra Estado Islâmico. Mas um ano não fazer nada. Rússia um mês! [e exalta e gesticula com a mão indicando que já está resolvido]. Agora América paga 1 milhão de dólares para terroristas...1 milhão! vai parar na mão de terroristas. Mas quase todas pessoas em Brasil falou [falam que] Bashar Al-Assad não bem [não é bom]. Mas ele fazer Síria muito forte, ele fazer Síria muito bonita, ele fazer Síria muito, muito forte [fala com orgulho]. Mas Arábia Saudita, Qatar, Turquia quer tirar Assad. Por quê? América fazer guerra Iraque e Iraque acabou. Terrorista depois [terroristas chegam em seguida]. América fala precisa fazer pez [paz] com Israel. Ele [Bashar] fala não. Israel tem guerra com Síria em Golã. Ele fala não: Israel voltar Golã eu fazer pez [Israel devolve Golan então eu faço a paz]. Mas América, Europa, fazer média internacional.

É patente a sua insatisfação em perceber o quanto a mídia ocidental reforça os projetos de algumas potências para Bashar Al-Assad. Além disso, ressalta a postura firme de seu presidente com relação a Israel que durante a Guerra dos Seis Dias de 1967 anexou as Colinas de Golã, anteriormente território sírio.

Questiono qual o peso das diferenças sectárias para o conflito, se elas são preponderantes, e como essas diferenças, que tem seus simpatizantes e que polarizam os apoios, como Síria, Irã e Hezbollah de um lado e Turquia, Qatar e Arábia Saudita de outro, influenciam o conflito. Issa responde:

você sabe: muslimano tem suni e shi'i. Quase todo árabe é suni. Mas Bashar shi'i, Irã, shi'í. 1400 anos suni e shi'i em guerra. Até agora não tem pez [paz - e bate as mãos em sinal de inexistência]. Bashar shi'i, precisa shi'i [justificando a ajuda do Irã e outros grupos xiitas]. Na Síria não tem problema, suni, shi'i, cristianos [cristãos]...não tem problema. Se presidente fazer bem, não tem problema. Ele [Assad] shi'i mas fazer Síria muito bem, tem dinheiro bom, muito forte. Salário pessoas antes, muito bom [se exalta, demonstra alegria].

Como se nota, apesar da superficialidade da explicação é possível tirar como lição do ponto de vista de Issa, que a questão envolvendo divisões religiosas não é o principal fator do conflito, uma vez que as divergências entre sunitas e xiitas são muito antigas e, além disso, o presidente garante a harmonia religiosa em um país tão diverso como retratado por Issa.

Sobre o EI, ele brevemente comenta que "não são muslimano verdadeiro. Se muslimanos apoia [apoiassem] Daesh, por que matam muslimano?" Nesse caso, o Daesh não representa a comunidade muçulmana, pois é justamente ela quem mais tem sofrido 
em razão do avanço desse grupo. No entanto há que se fazer uma ressalva em dois pontos nessas últimas falas. A primeira contém traços avessos às políticas ocidentais criticando a forma e a eficácia de suas intervenções não só no atual conflito, mas em outros mais antigos e que teriam influência na situação presente. Outro detalhe que chama a atenção é ter mencionado que os EUA enviam dinheiro para terroristas, nesse caso o EI (Daesh). Isso nos leva ao segundo ponto que também será observado quando da exposição do núcleo de Alaa El-Deen, sobre a questão de teorias conspiratórias. O EI seria uma criação sionista-americana com o intuito de desestabilizar a região para fins de domínio econômico e político. Demant (2015a) corrobora com essa afirmação ao dizer que "na região, muitos acreditam em teorias conspiratórias absurdas de que o EI é uma invenção dos EUA ou de Israel".

A conversa então é interrompida, pois já começava a ficar tarde e Issa já demonstrava ansiedade para terminar até porque precisava pegar um ônibus para retornar para casa. Ele apenas finaliza reforçando algo que sempre disse em todas as vezes que nos falamos: "quero trabalho, trabalho, trabalho...melhor trabalho. Eu falo [para] amigos: preciso olhar outro trabalho. Salário é pouco...Aqui quase R $\$ 1.000$, e só aluguel [da] casa, 800 reais”. Ao final desse encontro entreguei um jogo de cobertores e roupas de cama como doação que ele mesmo havia pedido. Ele, ainda com uma postura um tanto constrangida, agradeceu, me abraçou, virou as costas e desapareceu na penumbra da noite que caía.

\section{Aladdin sem lâmpada}

O segundo núcleo de refugiados que tive contato direto é composto por Mouhamad, de 18 anos, Alaa El-Deen, 24, - que inclusive pediu para chamá-lo de Alaa ou Aladdin como o do desenho da Disney - e Hoda, 44, mãe de Mouhamad e tia de Alaa El-Deen, todos oriundos de Damasco, capital da Síria. Também estão com eles outras quatro pessoas entre primos e sobrinhos, mas que não estavam presentes. 0 encontro aconteceu na sede da Sociedade Islâmica de Campinas no dia 04 de novembro de 2015 e foi mediado por Nader, secretário da Sociedade Islâmica de Campinas. Foi ele quem auxiliou no agendamento desse encontro e nas traduções de algumas falas.

Hoda, usando o hijab, era a mais tímida e com maior dificuldade com o idioma local e apenas observou a conversa que se concentrou nos rapazes, os alegres e sorridentes Mouhammad e Alaa.

Inicialmente, pedi para que dissessem como era a vida em Damasco antes do conflito e o que motivou a vinda para o Brasil. Responderam que têm uma marmoraria nos arredores da cidade e que enquanto lá residiam, tinham uma vida digna com algumas posses. Notei que fizeram o uso do verbo no presente, "temos uma marmoraria". Isso porque parte da família que ainda reside na Síria insiste em não fugir. Alaa diz: "tem pai, mãe e tem irmão... mas não vão para outro país...tá difícil...não querem sair, tem casa, empresa, deixa tudo vai pra outro país, não querer...mas tão bem, graças a Deus". Entretanto, um dos fatores que 
motivaram a vinda para o Brasil é que apesar de estar em Damasco, segundo eles "um local menos complicado, pois está perto da casa do presidente", é que a "casa e fábrica... destruiu com guerra. Todo dia tem ataque". Mouhamad acrescenta que "dois irmãos da minha mãe faz quatro anos não saber onde está". Sua casa e fábrica foram atingidas e parcialmente destruídas em um dos ataques. 0 conflito tinha encontrado essa família que escolheu o Brasil pelo mesmo motivo de tantos outros: a facilidade em se obterem vistos.

A família de Alaa desde que chegou há cerca de um ano, já morou em São Paulo por três semanas, mas foi uma experiência ruim na visão dele: "Eu morar [morei] em São Paulo...mas não gostei...muita gente, muito carro...aqui mais calmo". Campinas, apesar de mais "calma", também cobra um preço alto pelo custo de vida, fazendo com que, a exemplo de Issa que se deslocou para Sumaré em busca de aluguel mais barato, eles fossem morar em Hortolândia. Desde que chegaram, Alaa e Mouhamad já trabalharam na área da construção civil (como pintor e ajudante de pedreiro), mas estão desempregados há mais de 3 meses.

Aprofundando a conversa, questionei sobre a política síria, com relação à presença de Assad e de outras pessoas que querem sua saída. Aqui há um ponto de divergência entre Issa, que defende a permanência de Bashar Al-Assad, e Alaa que afirma: "nós não gostar de Assad...muito dictador. Sabe dictador?". E eu acrescentei: e se não existisse o EI, mesmo assim teriam deixado a Síria? E ele responde laconicamente: "é complicado". Insisti em saber qual a opinião dele sobre a possível saída de Assad e Alaa me interrompe no meio da pergunta dizendo: "Assad não sai. Difícil. Muito difícil. Mas se sai, fica pior. Sabe, agora tem o Daesh, Al-Qaeda. Mas a Rússia ajuda presidente. Irã também. Hezbollah libanês também".

Nader então exprime sua opinião sobre o conflito com base na fala de Alaa:

não tem absolutamente nada de religioso [e aumenta a entonação]. São conflitos políticos. Tudo isso que tá acontecendo lá é em função da geopolítica mundial. Só que a gente analisar o que o Alaa tá falando... tem um presidente e tem grupos contra...rebeldes, por exemplo o Estado Islâmico, a Al-Qaeda. Se a gente analisar essa conjuntura a gente vai ver que esses grupos também são grupos políticos. Quando houve o desmantelamento da URSS e a Rússia ficou isolada, pois as demais repúblicas lutaram pela independência...com desmembramento daquela estrutura, algumas repúblicas do Oriente Médio também ó [e bate com as mãos] largaram mão dos soviéticos. Só que o Bashar Al-Assad...o pai dele... [e Alaa intervém lembrando o nome de Hafez Al-Assad]...o pai dele Hafez por exemplo, e o próprio Bashar, eles mantiveram aliados aos russos. Então o que aconteceu? Os EUA foram lá e arrebentou....eles compraram Saddam Hussein, depois transformaram ele num vilão, arrebentaram com ele. Depois o Ghadafi, arrebentaram com ele. E olha como esses caras morreram! [exclamou]. Então os americanos vão ocupando aquela região dessa maneira. Então, como Bashar manteve-se aliado aos russos, então os russos não deixam ninguém entrar lá. Eles têm o poder de veto dentro do conselho de segurança da ONU. Então ninguém pega, ninguém tira o Bashar de lá! [exclama mais uma vez]. Os 
americanos patrocinaram esse grupo de jovens rebeldes que pegaram no Oriente Médio, Europa e Ásia - tem indiano, paquistanês, tem europeu - a maioria é de vagabundo.

Nesse ponto Alaa interrompe novamente concordando com o exposto por Nader e complementa que esses jovens aliciados "estão felizes, pois não tem o que fazer no país deles...desempregados".

Nader continua:

os americanos patrocinam, deram treinamento para eles na Inglaterra, providenciaram armas e os britânicos treinaram. Lê nas entrelinhas o quanto de sujeira tem por trás disso. E quem paga o pato? O povo! [apontando para os refugiados ali presentes]. Esses grupos que tão lá, todos eles hoje representam uma ameaça. Você [apontando para mim] perguntou se o Bashar sair....Vai ficar muito pior! [exclama]. Porque é um bando de maluco, tudo interesseiro, estão lá pelo dinheiro e pelo poder, ninguém quer saber de religião.

Mais uma vez fica nítida a mágoa com relação ao ocidente, representado por britânicos e norte-americanos, e novamente vêm à tona argumentos ancorados em raciocínios conspiratórios uma vez que não há provas cabais de que tais potências patrocinam e treinam grupos jihadistas como o EI em prejuízo da população local e em benefício de cálculos político-econômicos.

Sobre isso quis que eles dissessem o que pensam do EI, se ele representa os muçulmanos e a religião. Compactuando com a impressão de Issa, Alaa, Hoda, Mouhamad e Nader em tom uníssono e sacudindo a cabeça negativamente respondem: "de jeito nenhum!". Nader acrescenta:

a gente vê daqui do ocidente esses vagabundos lá matando pessoas de forma bárbara, de forma horrosa...aquilo é assassinato! Dizem Allahu Akbar! E corta a cabeça do cara! Taca fogo em outro! 0 que é isso? [se exalta]. No Islam tem um versículo no Corão que se você mata um inocente equivale a ter matado a humanidade toda. É um pecado gravíssimo! Você não pode tirar a vida de ninguém. Então o que esses vagabundos estão fazendo não é o Islam, isso é política, isso são grupos, guerrilhas armadas que não tem vinculo nenhum com a religião.

Há que se ter coragem de assumir ou ao menos considerar a hipótese de que esses grupos são de muçulmanos. A discussão de serem ou não serem muçulmanos suscita a questão de que um grupo microscópico não deve ser confundido com os muçulmanos de um modo geral e especialmente com a religião em si. Para Demant (2015b:34) "o dilema central parece recair na dificuldade em diferenciar a crítica da religião da crítica dos muçulmanos como grupo. Precisamos distinguir dogmas, crenças e visões de mundo de um lado, de indivíduos e grupos de outro" (tradução livre do autor desse artigo) ${ }^{15}$.

\footnotetext{
15 "the central dilemma seems to lie in the difficulty to differentiate critique of religion from criticism of
} 
Há uma grande heterogeneidade entre os muçulmanos, que assim como judeus, cristãos ou budistas, há aqueles que se valem da religião para rejeitar a modernidade e seus modos de vida. Há, portanto, que se distinguir entre os militantes que buscam islamizar sua sociedade, os que tentam explodi-la por não conseguir islamizá-la, e os mais "quietos" que evitam a política completamente (Ruthven, 2005) ainda que existam componentes na religião islâmica cujas interpretações conduzam para a incompatibilidade com a democracia, pois a única soberania provém de Deus. Enfim, enquanto de um lado uns tentam repudiar alguns atos violentos valendo-se da negação de que esse ou aquele grupo seja muçulmano e por outro haver uma espécie de generalização da culpa, será difícil aparar as arestas que tanto distanciam o diálogo entre "nós" e "eles".

Em um momento seguinte, instiguei Alaa sobre a questão sectária em seu país e o modo como isso pesa para o conflito. Nader então traduz sua resposta:

ainda tem problema entre alauíta, xiita e suni...quando Saddam Hussein foi derrubado do poder, teve seu grupo de fiéis, que eram da cúpula do exército... esse grupo é sunita e se manteve fiel a Saddam Hussein. Então eles [EI] têm treinamento, são militares, são profissionais e tem armas.

Como a continuação da explicação foi um tanto redundante, pois se concentrou em explicar a origem da divisão entre xiita e sunita, interrompi então para saber se ele e sua família são sunitas, xiitas ou alauíta. Alaa assevera categoricamente: "sou muçulmano"16. Nader acrescenta que para discutir essas questões no ocidente é muito difícil "porque a população ocidental mal sabe o que é o Islam. 0 que acham que é o Islam? Terrorista! Homem-bomba! Barbudos!". Alaa aproveita a deixa e brinca: "eu uso barba só porque gosto, viu! [muitos risos]".

Brincadeiras à parte, a alegação que há no Brasil um grande desconhecimento acerca do Islam e seus seguidores,-é verdadeira, ocorrendo generalizações negativas, por vezes pejorativas e depreciativas. Muito disso veiculado pela mídia internacional e especialmente a nacional. Há um estudo de Castro (2007) que mostra a forma em que dois dos maiores jornais brasileiros, $\mathrm{O}$ Estado de S. Paulo e a Folha de S. Paulo, representam os árabes e muçulmanos seis meses antes e seis meses depois dos atentados de 11 de setembro de 2001 . Esse trabalho aponta que as principais manchetes e notícias do período vinculavam o Oriente Médio, os árabes e os muçulmanos à violência e ao atraso. Com a atual crise na Síria, isso Muslims as a group. We need to distinguish dogmas, beliefs and worldviews on the one hand, from individuals and groups on the other".

${ }^{16}$ Sobre as questões sectárias, Nader narra uma anedota a título de exemplificação: "a gente não vê diferença. Tem até uma piada que a gente conta de um debate entre um sheikh sunita e outro xiita. Só que eles combinaram de fazer esse debate na mesquita xiita. Aí quando o sheikh sunita entrou lá, ele tirou o chinelo e colocou debaixo do braço e pisou no carpete. Aí o sheikh xiita falou: 'espera aí, para com isso! Por que você está entrando com um chinelo? Coloca na estante lá.' Aí o sheikh sunita disse: 'não, é ensinamento do profeta que quando se entra numa mesquita xiita deve-se colocar o chinelo debaixo do braço'. E o xiita responde: 'mas na época do profeta nem existia xiita!' E o sheikh sunita então diz: 'então acabou o debate' [risos]”. 
acaba por reforçar estereótipos que podem em alguns casos se transformar em preconceitos com consequências mais graves, que no caso dos refugiados sírios, poderiam eventualmente se deparar com episódios de xenofobia, com rico material jornalístico e testemunhal entre os muçulmanos que vivem no Brasil que retratam episódios de xingamentos e outros tipos de agressões às mulheres usando hijab, por exemplo.

Questionei também qual o ponto de vista deles sobre a questão do fundamentalismo islâmico. Alaa, através da tradução de Nader, afirma que "não pode generalizar. Nem todo muçulmano é radical. Não gosta e não aceita, eles são minoria. Tem muitas informações que a mídia sionista traz que são falsas".

Esse trecho é passível de três comentários breves. 0 primeiro é com relação ao fundamentalismo, ele é visto por Alaa como algo negativo, ligado ao jihadismo. Segundo, que ao afirmar que os fundamentalistas (radicais em sua concepção) são minoria, então pode haver aqui uma contradição se levarmos em conta que o EI, sendo jihadista, é fundamentalista. Nesse caso, a contradição reside no fato de que se antes o grupo não era tido como muçulmano, agora, indiretamente parece o ser, mas parte de uma minoria dentre os muçulmanos do mundo. Em terceiro e último lugar, quando usaram a palavra sionista como adjetivo de mídia, interrompi sua fala para entender de que forma isso pode ser um problema. Então Nader traduz a explicação da seguinte forma:

\begin{abstract}
Não posso dizer que há problema com judeu...ele é um crente como outro qualquer, judeu é meu irmão. Tanto é que a gente usa a palavra sionista, o sionismo que já é uma estrutura política, paramilitar, que foi quem elaborou a criação do Estado de Israel, desde Theodor Herzl, que elaborou um plano para em 50 anos se criar o Estado Judeu. Aí eles tinham opções mas optaram pela palestina pois era o único país no mundo que não tinha milícia, não tinha exército, não tinha quem protegesse sua fronteira. E em 1948, se criou o Estado de Israel. Não tenho nada contra o judeu. 0 problema é o sionismo. 0 judeu não é o problema, é o sionismo [enfatiza].
\end{abstract}

Aqui cabe a reflexão sobre o emprego do termo "judeu". Para Alaa seria cultura, religião, povo, traço étnico ou nacionalismo? Provavelmente, inconscientemente ele "desetniza" o judeu, separando o marcador cultural e étnico do religioso, quando na verdade, o judaísmo é um exemplo característico de religião étnica (Roy, 2008).

Essa separação é aspecto comumà fala de muitos muçulmanos na tentativa de exaltar sua tolerância religiosa, mas de criticar o nacionalismo secular judaico que "coloniza" terras palestinas e que deve, portanto, ser combatido enquanto prática imperialista de Estado segundo sua visão.

Além disso, ele também indica uma separação entre aquilo que crê representar o Estado de Israel e sua política imperialista, da etnia, religião e povo judeu, que além de ser mais antigo que o próprio Estado moderno israelense, muitos deles não simpatizam com as políticas atuais de seu país. Ao mesmo tempo tem em mente que em termos religiosos 
os judeus são um dos povos do "livro", assim como cristãos, e nesse caso deve-se conceder um tratamento respeitoso e indulgente.

Após esse bloco de reflexão, da mesma forma como fiz para Issa, perguntei qual foi o "choque" ao chegarem ao Brasil, quais foram as principais diferenças em se tratando de culturas bem distintas. Além disso, se sofreram algum tipo de preconceito aqui. Alaa diz:

adoro Síria. Nasci lá. Quero voltar para lá [demonstrando muito orgulho]. Aqui é muito diferente de lá. Por exemplo, olha mulher aqui: aqui não fecha cabelo [não se usa o véu]...por exemplo...a gente...comida...não pode comida de porco... cerveja...mas eu bebo e fumo [risos]. 0 que faz falta quando ir embora é a simpatia de brasileiros. Sempre trata bem, com sorriso. Na Síria, um pouco mais fechado. Mas agora no Brasil tem crise...esse difícil....pouco salário, pouco trabalho....acho que Brasil pobre também. A gente precisa, mas o brasileiro precisa mais. Agora por exemplo: quanto tá o dólar? Quase quatro!

Se o Brasil tem apresentado dificuldades do ponto de vista econômico e mesmo com relação ao idioma, um complicador na hora de conseguir trabalho, interpelei se não seria mais fácil eles irem para outro país árabe-muçulmano mais próximo, como Egito ou Jordânia, por exemplo, até por afinidades culturais e linguísticas. Alaa explica "que lá não pode, não tem visto. Brasil, olha só...muito longe, mas visto fácil. Eles [Egito e Jordânia] abre porta e depois fecha rápido". Nader complementa:

a política nesses países árabes, se partir da lógica da língua e da cultura como você [apontando para mim] disse ser um facilitador, mas é a política que manda. Então esses governos não abrem espaço para os sírios, não abrem espaço para entrar...é como o Alaa falou: abre um período pequeno, dá uma janela e depois fecha rápido. Porque são países em crise, estão em uma situação ruim também, a vida lá é dura, também tão desempregados, passam fome. Para o Líbano foram vários sírios, cerca de 1 milhão, mas o país é pequeno, você praticamente dobra a população [há aqui um certo exagero quanto à quantidade informada]. Quando se abre a oportunidade como o Brasil, de receber sírios, desde que os custos sejam deles, há maior fluxo para cá. Só que quem atravessa o oceano, são pessoas que têm condições [financeiras]. Então a gente fala, até para prefeitura de Campinas: olha, o governo brasileiro recebeu de graça mão-de-obra qualificada. A especialidade desse aqui é mármore [apontando para Alaa], outro vizinho deles trabalha com pintura, decoração mais alto nível, eles têm conhecimento lá que aqui você não vê. Tem médicos, engenheiros...tem pessoas que vem de um bom nível profissional.

Após esse comentário, percebo que Mouhamad e Alaa falam algo em voz baixa para Nader. Então ele diz que ele teria que levar a família de volta para casa para "arrumar as coisas" e passar em uma casa de câmbio para trocar dinheiro. Estranhei e perguntei se estavam de mudança. Nader se antecipa a Alaa e me revela algo muito importante: 
no domingo, dia 08 de novembro de 2015, quatro dias após nosso encontro, essa família estaria de partida do Brasil. Iriam para a Turquia para então tomar um barco e atravessar o Egeu até a Grécia. Alaa complementa demonstrando uma grande preocupação com a travessia: "você viu criança morta na praia em Grécia?...mas o que faz? Pode ser que alguém de meu família não consegue [diz isso com cabeça baixa e voz em tom melancólico]". Há um momento de silêncio rompido com minha pergunta para qual país europeu tem preferência. Alaa afirma ser "Alemanha, Suíça ou Suécia...eu vai ver quando chegar lá...está na mão de Deus...lá temos que aprender a língua, mas acho que vai ter mais oportunidade que aqui. Lá tem apoio de governo". Descobri posteriormente que a maior intenção era a Suécia pelo fato de lá já ter um parente, um tio.

A crise econômica do país, se ruim para brasileiros, é ainda pior para eles, que sem emprego e sem apoio do Estado, não conseguem uma vida digna no Brasil. Além disso, outro fator que revelaram ser importante na decisão para ir embora foi a violência. Nesse instante houve alguns risos de constrangimento por parte de todos os presentes, especialmente dele e de Nader, uma vez que é uma situação um tanto ambígua já que saíram de um país em guerra civil, mas têm medo da violência do Brasil. Alaa, já em um tom mais sério, citou o exemplo de sua prima que trabalha em uma pizzaria em Hortolândia e que passou por um assalto a mão armada, algo pouco comum na Síria segundo ele. Assumiu que tem medo por não dominar o idioma e ser morto em um assalto pelo fato de que o suposto delinquente possa não compreender o que dizem.

Em suma, eles têm plena consciência dos riscos que os esperam e confessam o medo de que ao final dessa odisseia nada idílica, nem todos poderão estar juntos. 0 mar pode reivindicar sua parte.

No final, me recordo do famoso desenho da Disney "Aladdin", de 1992, quando o protagonista Aladdin surge com seu fiel e simpático amigo, o macaquinho Abu, pulando e cantando sobre os telhados da cidade de Agrabah: "tenho que correr e ser ligeiro/ Pular/ Pra me livrar". Qualquer semelhança não é mera coincidência, pois assim como nosso Alaa El-Deen, o movimento e o perigo parecem uma sina. Mas se ele tivesse uma lâmpada mágica como no desenho, creio que não precisaria usar os três desejos. Bastaria um: voltar ao seu lar. Em paz. Incha'allah!

\section{As Ações do Poder Público Municipal}

Após conhecer alguns anseios, perspectivas e dificuldades encontradas por alguns dentre as dezenas de refugiados em Campinas e sua região, cabe perguntar: como o poder público tem agido em prol dessas famílias. Quais são as ações promovidas? De que ponto de vista examina a atual conjuntura? Quais secretarias estão engajadas para dar suporte aos refugiados? Há algum programa para refugiados? Para tentar encontrar algumas 
respostas, no dia 08 de novembro de 2015, houve um evento ${ }^{17}$ na Sociedade Islâmica de Campinas que entre os objetivos, era o de promover uma conversa e apresentação de propostas e ações acerca da questão dos refugiados, principalmente sírios e haitianos. Estavam presentes membros de secretarias municipais, da Câmara dos Vereadores, alguns membros da Sociedade Islâmica de Campinas e refugiados, cerca de 20 deles, a maioria haitianos.

O vereador Pedro Tourinho exaltou a política nacional de acolhimento de refugiados, de concessão de asilo, frisando que essa acolhida, entretanto, consiste apenas em facilitar vistos e documentos como a carteira de trabalho, mas não promove meios de acesso aos direitos que muitos brasileiros têm, em tese, à moradia, saúde, educação entre outros. Há muito mérito no número de pessoas acolhidas ${ }^{18}$, mas não no seu atendimento em termos de direitos e mesmo em orientação a partir do momento em que pisam em solo brasileiro.

Para ao menos reduzir esse hiato entre a mera acolhida e o amparo legal, é premente que se reveja, atualize e por fim seja substituído o obsoleto Estatuto do Estrangeiro (lei n. 6.815 de 19 de agosto de 1980) ${ }^{19}$. Para esse propósito está em trânsito no Congresso Federal, o projeto de lei 2016/2015 ${ }^{20}$, chamado de Lei de Migração ${ }^{21}$ de autoria do senador Aloysio Nunes. Nesse projeto, as garantias, direitos e deveres dos imigrantes estão tipificados de forma mais objetiva além de promover uma maior desburocratização de alguns procedimentos. Também há uma maior clareza com relação aos princípios que nortearão política migratória, a exemplo do artigo 3ํ (Dos Princípios e Garantias). Existe também uma modernização quanto ao vocabulário empregado no contexto atual das migrações, como por exemplo, o emprego da palavra xenofobia que sequer é mencionada no Estatuto do Estrangeiro de 1980. Por fim, deve se ressaltar a promessa em agilizar a naturalização de pessoas, especialmente no caso de apátridas. Nesse caso específico, o então ministro da justiça José Eduardo Cardozo assinou um aviso interministerial encaminhando à Casa Civil um projeto de lei que reconhecerá como brasileiras pessoas sem nacionalidade reconhecida por algum Estado ${ }^{22}$.

\footnotetext{
17 "Saúde da Mulher e a Questão dos Refugiados em Campinas".

${ }^{18} \mathrm{O}$ número de refugiados acolhidos pelo Brasil segundo o vereador, chega a ser maior que o dos EUA. Porém, quando comparamos com o número de outros países como a Turquia, Jordânia e Líbano, por exemplo, não há muito que celebrar. Pois em cinco anos, respectivamente, esses países acolheram cerca de 2.739,326, 655.217 e 1.048,275 de sírios. (http://data.unhcr.org/syrianrefugees/regional.php\#_ga=1.87420561.8623 38619.1467139081 acesso em 28/06/2016).

${ }^{19}$ Nos 118 artigos, o projeto trata de assuntos como situação documental do imigrante; registro e identidade civil; controle migratório; repatriação, deportação e expulsão; opção de nacionalidade e naturalização; direitos do emigrante brasileiro; medidas de cooperação, como extradição, transferência de execução de pena e transferência de pessoas condenadas; e infrações e penalidades administrativas.

(http://www12.senado.leg.br/noticias/materias/2015/07/02/projeto-de-lei-de-migracao-e-aprovadopela-comissao-de-relacoes-exteriores - acesso em 08/12/2015).

${ }^{20}$ http://www.planalto.gov.br/ccivil_03/Leis/L6815.htm (acesso em 08/12/2015).

${ }^{21} \mathrm{http} / / /$ www2.camara.leg.br/proposicoesWeb/fichadetramitacao?idProposicao=1594910 (acesso em 08/12/2015)

${ }^{22}$ http://www.brasil.gov.br/cidadania-e-justica/2014/08/nova-lei-de-migracoes-devera-substituirestatuto-do-estrangeiro (acesso em 08/12/2015).
} 
Contudo, essas ações ainda estão no plano legislativo a caminho de aprovação. A sobrevivência desses refugiados bem como uma vida digna em nosso território não pode acompanhar o ritmo da máquina pública. Nesse caso, as ações ainda têm sido bastante tímidas no tocante à inserção desses refugiados na sociedade e no gozo de seus direitos que muitos desconhecem por falta de orientação. Tais ações partem principalmente de ONGs, de práticas solidárias individuais com doações daquilo que necessitam para sua sobrevivência, de algumas entidades religiosas como a Catedral Metropolitana Ortodoxa e a Cáritas Arquidiocesana de São Paulo $^{23}$ e seu centro de acolhida para refugiados; o Lar Sírio Pró-Infância; Centro de Referência e Acolhida para Imigrantes (CRAI) da Prefeitura de São Paulo, o Comitê Migratório Sírio; as Sociedades Islâmicas, a exemplo da Sociedade Islâmica de Campinas; universidades e alguns de seus departamentos, como o Departamento de Geografia da Universidade de São Paulo (USP) com o oferecimento de $\operatorname{cursos}^{24}$ para refugiados sobre o Brasil e o novo contexto de vivência visando facilitar sua adaptação ao país.

Voltando à esfera municipal, Tourinho disse ter criado uma Comissão Especial de Estudos (CEE) "para acompanhar e observar as ações promovidas pelo poder público quanto aos refugiados para que eles consigam acessar os seus direitos como à saúde, moradia, trabalho e educação".

Ele pede que os imigrantes sejam os protagonistas dessa comissão,

trazendo para nós os problemas que têm enfrentado. A gente já ouviu, por exemplo, que apresentaram problemas bastante interessantes que eu jamais teria pensado mesmo nascido e criado no Brasil, como a dificuldade para alugar um imóvel, das situações de extorsão que sofrem quando se apresentam como imigrantes em situação precária e incerta. Por exemplo, quando não encontram fiador acabam sendo extorquidos tendo que pagar o dobro. Outra dificuldade evidente é a língua tanto para os sírios como haitianos. Felizmente nós temos a Secretaria de Educação da cidade oferecendo curso de línguas para parte desses imigrantes dentro do programa de educação de jovens e adultos (EJA). Todas essas questões nós temos buscado escutar e o que a gente quer na verdade é convidar toda essa comunidade de Campinas que compartilha de uma história comum como o caso dos sírios, de crenças, de valores, que venha se integrar e apoiar o trabalho dessa comissão para que a gente possa enxergar, antes de mais nada, quais são os principais problemas que as pessoas vivenciam hoje e dessa forma poder abordar essas questões a partir da ótica da política pública. A gente entende que a melhor maneira de garantir às pessoas boas condições de subsistência, de construção de uma vida no Brasil é integrando as pessoas à cadeia de políticas públicas que todo brasileiro tem direito (TOURINHO, 2015) ${ }^{25}$.

\footnotetext{
${ }^{23}$ http://caritasarqsp.blogspot.com.br/ (acesso em 08/12/2015).

24 http://www.saopaulo.sp.gov.br/spnoticias/lenoticia2.php?id=243048\&c=6 e http://www5.usp. br/99926/na-usp-refugiados-aprendem-geografia-do-brasil-e-encontram-apoio-para-adaptacao-ao-pais/ (acessados em 08/12/2015).

${ }^{25}$ Depoimento realizado em evento na Sociedade Islâmica de Campinas/SP em 08/11/2015.
} 
O vereador também narra um caso de um imigrante sírio que lamentou o fato de que somente após um ano desde quando chegou a Brasil alguém enfim teria dito como faria para revalidar um diploma de graduação obtido em seu país. Essa seria umas das dificuldades que se enquadram naquilo que a comissão pretende dirimir.

Tourinho ainda afirma que "um quadro que nossa comissão observa, são ações de combate ao preconceito e discriminação de qualquer ordem, seja do ponto de vista religioso, racial, cultural. A comissão é um espaço para denúncia e enfrentamento dessas questões". Conclui dizendo que "a Secretaria de Assistência Social através do Departamento de Cidadania tem feito um trabalho bastante intensivo, bastante vigoroso de estruturação de ofertas e articulação de uma rede de apoio e solidariedade aos imigrantes"26.

Segundo o Departamento de Cidadania, em Campinas já são ministradas aulas de português ${ }^{27}$ para os refugiados, e no caso dos sírios existem duas classes com 34 pessoas cada $^{28}$. Iniciativas também estão sendo tomadas junto ao Departamento Estadual de Trânsito (DETRAN) sobre a carteira nacional de habilitação para os refugiados, que é uma das dúvidas que chegam à prefeitura por parte dos imigrantes.

É importante ressaltar que tanto a Comissão de Estudos Especiais como as secretarias e departamentos envolvidos, sinalizam com tímidas iniciativas ao apoio aos refugiados. Tais órgãos se encontram mais aptos a ouvir reivindicações e demandas do que propriamente em promover ações efetivas de inclusão dessas comunidades tendo em vista a carência de instrumentos normativos que proporcionem ações de forma mais rápida e precisa. Faltam também canais de comunicação para que essas comunidades de refugiados possam ser orientadas assim como uma maior integração com outras entidades religiosas e ONGs que se prestam a esse tipo de auxílio.

O simples fato de terem acesso à carteira de trabalho não os protege daqueles que visam explorar sua mão de obra e violar direitos trabalhistas. Não bastam cursos de língua portuguesa, há que disponibilizar meios de acesso às escolas públicas e creches ainda que por meio da firmação de convênios com particulares. Também é crucial encontrar mecanismos que facilitem sua inclusão no Sistema Único de Saúde (SUS) e também

\footnotetext{
${ }^{26}$ Um representante do Departamento de Cidadania, que participava do evento na Sociedade Islâmica de Campinas, disse também que a Secretaria Municipal de Cidadania, Assistência e Inclusão Social (SMCAIS) fez um estudo e apresentou ao prefeito quais as secretarias que serão envolvidas na questão dos refugiados. Elas seriam: Secretaria de Saúde, Educação, Defesa Civil, Assessoria Jurídica, Segurança, Recursos Humanos, Habitação, Trabalho e Renda, Esporte e Turismo.

${ }^{27}$ Endereços e espaços onde há aulas: Av. Campos Salles o CPAT (Centro Público de Apoio ao Trabalhador), com aulas de segunda a sexta-feira das $19 \mathrm{~h}$ às $21 \mathrm{~h}$; no Cescon (Centro Estudantil e Social de Convivência) da R.Francisco Alati em Barão Geraldo; Escola Estadual Clotilde, no Parque Florença 2.

28 "Hoje a Educação de Campinas conta com três salas de haitianos, com 45 alunos no total, além de duas salas com sírios, que somam 34 pessoas", afirmou Marinalva Cuzin, representando o Conselho do setor. http://www.campinas.sp.leg.br/comunicacao/noticias/2015/outubro/em-reuniao-da-cee-de-refugiadosconselhos-municipais-de-educacao-e-saude-revelam-medidas-na-area-para-receber-sirios-e-haitianos (acesso em 08/12/2015).
} 
fiscalizar e coibir quaisquer formas de preconceito que eventualmente possam ocorrer, especialmente a xenofobia. Essas e tantas outras necessidades devem entrar na pauta do poder público o mais depressa possível, que não pode se limitar a apenas ouvir as dúvidas e demandas desses grupos de refugiados. Caso contrário, veremos cada vez mais famílias como as de Alaa, deixando nosso país para engrossar as filas de desesperados que querem entrar na Europa sem garantia de sucesso.

\section{Considerações Finais}

Usando como método a oralidade, passamos a ouvir "vozes ocultas" que narram suas histórias que por sua vez auxiliam na compreensão de um quadro maior. É evidente que o tempo não permite um acesso constante e ilimitado a esses informantes a fim de obter informações mais acuradas e precisas. 0 tempo é crucial no estabelecimento de pontes de confiança entre o entrevistador e os entrevistados, que nesse caso encontramse em uma situação muito vulnerável do ponto de vista econômico e social, fragilizados pela guerra, pela distância de sua terra, de suas famílias e da perda de dignidade. Coragem, todavia, não falta a essas pessoas que se arriscam de diversas formas para sobreviver.

Um exemplo dessa volatilidade enquanto fontes de informações é o caso de Alaa e sua família que já não se encontram no Brasil. Aliás, a última notícia de que disponho é que felizmente conseguiram completar a travessia e hoje estão instalados na Alemanha. Mas através de redes sociais é comum ver depoimentos tanto de Mouhamad como de Issa demonstrando saudades do Brasil e dos amigos que aqui fizeram. Issa, ainda que possa contribuir com outros futuros encontros e novas informações, não garante que ficará por muito tempo caso não possa cuidar de sua família com seu trabalho que por sua vez não é estável.

As informações que foram obtidas, apesar do contato não ter sido tão longo quanto o desejado, são valiosas na medida em que nos fazem refletir sobre diversos assuntos do ponto de vista das maiores vítimas desse conflito. Suas opiniões sobre o conflito e temas correlatos, concepções sobre certos assuntos envolvendo sua religião, a forma como chegaram ao Brasil e como aqui vivem abrem um terreno fértil de estudos que poderão surgir a partir dessa recente onda imigratória.

A retórica empregada em muitos dos discursos e narrativas registradas são unidas por traços de teorias conspiratórias e por um sentimento avesso às políticas ocidentais, conduzidas por potências europeias e pelos EUA, mas difusas em termos de suas preferências políticas em relação ao seu país e seu comandante maior. Nos casos estudados, vimos que de forma unânime rejeitam a violência praticada pelo EI, mas fazem isso negando o caráter islâmico desse grupo como se purificassem a religião. Mas ao fazer isso talvez estejam se eximindo de certas responsabilidades em combater o grupo não pelas armas, mas pela ideologia tolerante que afirmam ter. A solução não passa por 
ignorar ou externalizar o problema ao dizer que "não são muçulmanos" ou "que é culpa das intervenções ocidentais", mas tomando-o para si tendo em vista oferecer mais uma possibilidade para o diálogo e mostrar ao mundo um Islam de paz, tolerante e moderado. Essa maioria moderada deve tomar espaço na mídia, ainda incipiente, e fazer-se sobressair perante as minorias que distorcem e sequestram a religião em nome do poder e da política (Barbosa, 2015). Como afirma Barbosa (idem:159), "é preciso que os muçulmanos deixem de falar para eles mesmos e proponham um diálogo com o Ocidente".

Outro ponto a ser sublinhado é se o poder público estará preparado para acolher essas pessoas. As medidas que dispomos ainda são tímidas, com leis antigas e morosas, que não acompanham o atual processo imigratório e enleiam as ações dos órgãos públicos que se tornam apenas mecanismos consultivos.

0 grande desafio é acompanhar essa totalidade dinâmica que é o mundo. A sua apreensão é fugaz dada a velocidade dos seus eventos. 0 caminho aqui oferecido para tentar tanger a realidade foi através da história oral de algumas testemunhas errantes, de modo que sua voz possa servir para uma versão mais genuína e original de como o global se fragmenta em partes. E, através delas, criam-se paralelos, conexões e acabam condicionando e sendo condicionadas pelo local em que habitam.

\section{Referências Bibliográficas}

BARBOSA, Francirosy Campos. Charlie Hebdo e islamofobia. In: Revista Malala. São Paulo, v.3, n.5, nov. 2015. Disponível no endereço http://www.revistas.usp.br/malala (acesso em $05 / 12 / 2015)$.

CASTRO, Isabelle Christine Somma de. Orientalismo na imprensabrasileira. Arepresentação de árabes e muçulmanos nos jornais Folha de S. Paulo e 0 Estado de S. Paulo antes e depois de 11 de setembro de 2001. Dissertação de mestrado, Departamento de Letras Orientais da Faculdade de Filosofia, Letras e Ciências Humanas da Universidade de São Paulo. São Paulo, 2007.

DEMANT, Peter. O EI se mantém por terror, intimidação e doutrinação. In: Gazeta do Povo. $14 / 11 / 2015 a$

Disponível no endereço http://www.gazetadopovo.com.br/mundo/entrevista-o-ei-se-mantempor-terror-intimidacao-e-doutrinacao-0ja2x7h4xgacoump1bd2hg1ta (acesso em 20/11/2015).

. How to criticize Islam? Innocence of muslims and the war of representations in the mirror of the clash between radical Islam and islamophobia. In. Revista Malala. São Paulo, v.3, n.5, nov. 2015b. Disponível no endereço http://www.revistas.usp.br/malala (acesso em 05/12/2015). 
relato de campo

DOSTOIEVSKI, Fiodor. Os demônios. São Paulo: Ed.34, 2013 [1872]. p.332

HILU, Paulo Gabriel da Rocha Pinto. Islã: religião e civilização. Uma abordagem antropológica. Aparecida/SP: Ed. Santuário, 2010.

KOSIK, Karel. A dialética do concreto. Rio de Janeiro: Paz e Terra, 1976.

PERKS, Robert e THOMSON, Alistair. The oral history reader. New York: Routledge, 1998.

PORTELLI, Alessandro. What makes oral history different p.71. In. PERKS, Robert e THOMSON, Alistair. The oral history reader. New York: Routledge, 1998.

ROY, Olivier. La sainte ignorance. Le temps de la religion sans culture. Paris: Éditions du Seuil, 2008.

RUTHVEN, Malise. Fundamentalism: the search for meaning. New York: Oxford University Press, 2005.

THOMPSON, Paul. História oral e contemporaneidade. Palestra proferida na Universidade Federal de Minas Gerais. Belo Horizonte, 29 de agosto de 2000.

TOURINHO, Pedro. Depoimento realizado em 08/11/2015 na Sociedade Islâmica de Campinas/SP. 